\title{
Greening Spanish primary schools: students and teachers attitudes to centres committed to sustainability
}

\author{
María de Fátima Poza-Vilches ${ }^{1 a}$, José Gutiérrez-Pérez ${ }^{1}$, and Abigail López-Alcarria ${ }^{1}$ \\ ${ }^{1}$ Department of Methods of Research in Diagnosis \& Education. Faculty Sciences of Education. \\ University of Granada.Campus Universitario Cartuja, s/n. 18071. Granada (Spain)
}

\begin{abstract}
An environmental audit study is presented, based on the opinions of students and teachers about the possibilities of improvements to the environmental resource management of twelve primary education centres in the region of Andalucía (Spain), and the guidelines for implementing programs for curriculum greening that are committed to the environment and that makes it possible to undertake actions of sustainable development both inside and outside the classroom. The research follows a diagnostic methodology, focused on describing the models of environmental resources management at primary education centres in Andalucía, as well as their sustainability actions, commitments and programs from the perspective of both teachers and students. Finally, the results have been confirmed that there is a need to redefine the strategies for environmental management, intervention and participation of the entire educational community, approaching this from the design of educationally innovative actions focused on the socio-environmental problems of the local area.
\end{abstract}

Keywords: Diagnostic; greening; sustainable education; quality; improvement

\section{Introduction}

Environmental Education (EE) constitutes one of the crosscutting axes that must guide teaching processes in formal education, and involve the entire educational community.

Spanish regulatory framework (LOGSE, LOE, LOMCE) stipulates the compulsory requirement of environmental training in Primary Education, bestowing this subject with greater social relevance and making it a factor for territorial development and innovation.

As far back as the Conference on Environmental Education in Tbilisi in 1977, it was highlighted that EE must not become just another subject added to existing educational

\footnotetext{
${ }^{a}$ Corresponding author: fatimapoza@ugr.es
} 
programs, but must be integrated into the curriculum by the implementation of new concepts, methods and techniques for innovation and greening the curriculum.

There is no universal model for the integration of EE into the educational process, [10]. The approaches, modalities and the progression of the integration shall be established in function of the students' age, prior level of environmental knowledge and also in accordance to educational and socioeconomic conditions, objectives and the structures of each context.

Therefore it is fundamental to record the beliefs and attitudes that both students and teachers have with regards to the environment, as well as to characterise the teaching practice in order to identify shortcomings and potential, and to establish innovative proposals for improvement guided by the greening processes of the educational centres themselves.

Among the most important ideas highlighted in the literature in relation to formal education and focused on the Primary Education level are:

- Sustainable management, environmental protection and sustainable development issues in the educational sphere are generally from a transversal perspective of environmental education.

- Environmental education must be encouraged with extracurricular activities.

- Encourage centres to participate in local actions and launch Local Agenda 21 vs. School Agenda 21.

- Comprehensive environmental management at the centres considered as just another dimension of the curriculum.

- Design of explicit norms, agreed by the educational community, with regards to the protection, monitoring and management of environmental resources.

- Design of teaching strategies and innovations of a constructivist nature, based on the creation of solutions for environmental issues linked to students' environments.

- Active participation of students in the processes of the sustainable management of the centre.

- Promotion of a "Global Citizenship" dimension, where problems outside the immediate environment are considered.

An environmental audit study is presented, based on the opinions of students and teachers about the possibilities of improvements to the environmental resource management of twelve primary education centres in the region of Andalucía (Spain), and the guidelines for implementing programs for curriculum greening that are committed to the environment and that makes it possible to undertake actions of sustainable development both inside and outside the classroom.

\section{Objectives}

- To detect strengths and weaknesses in relation to the greening of the curriculum at primary education centres.

- To analyse student and teacher attitudes to sustainability at primary education centres in the region of Andalucía.

- To design educational actions agreed between teachers and students for the sustainable management of educational centres.

\section{Methodology}

The research follows a diagnostic methodology, focused on describing the models of environmental resources management at primary education centres in Andalucía, as well as 
their sustainability actions, commitments and programs from the perspective of both teachers and students.

\section{Strategies for collecting information}

- Scale for environmental attitudes addressed to students in the second cycle of primary education: Information collected as independent variables include the name of the school, the grade the student is in, their age and sex. As dependent variables, the scale has included 24 items with three response choices (disagree, neither agree/nor disagree, agree), where the surveyed students had to choose, in each case, the option that better reflected their behaviours and attitudes.

- Scale of environmental attitudes addressed to primary education teachers: As independent variables we have gathered data on sex, age, school, position or function at the educational centre, academic education, complementary training in environmental education, years of professional experience, whether they belong to any association and, where applicable, their level of responsibility within the group(s). The scale included 35 items, each with four response variables (from 1- totally disagree to 4-strongly agree).

The objective of both scales has been to evaluate student and teacher attitudes to different environmental problems: waste, energy, transport, water, awareness and environmental participation and healthy lifestyles. The tools employed included an integrated compendium of pre-existing scales -validated by experts-, whose objective is to evaluate this construct, $[12,17,2,5,1$ and 20].

- Questionnaire given to students on their perception of teaching competences on environmental protection issues: made up of 19 items with three response choices (disagree, neither agree/nor disagree, agree).

- Questionnaire given to teachers on teaching competences regarding environmental education: made up of 36 items with four response choices (from 1-totally disagree to 4strongly agree.)

Throughout both questionnaires different aspects related to the curriculum greening have been included with the objective of analysing teacher competences when facing the inclusion of environmental education in the curriculum, and to identify what type of strategies are carried out to promote sustainable development, not only at classroom level, but also at the centre as a whole.

\section{Characterization of the sample}

The sample is made up of 12 educational centres from across different provinces in Andalucía, with a total of 728 students in the 3rd and 4th grade of Primary Education, and 104 teachers distributed as indicated below:

- 728 students from the 3rd (50,5\%) and 4th (49,5\%) levels of Primary Education (7-10 years)

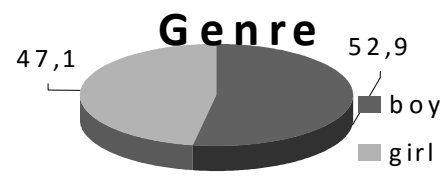

Fig. 1.Genre students.
Table 1. \% Provinces students.

\begin{tabular}{cc}
\hline \multicolumn{3}{c}{$\%$ PROVINCES } \\
\hline Córdoba & $7.4 \%$ \\
Granada & $8.2 \%$ \\
Huelva & $20.6 \%$ \\
Jaén & $20.3 \%$ \\
Málaga & $22 \%$ \\
Sevilla & $21.5 \%$
\end{tabular}


- 104 teachers: $78.7 \%$ are teaching graduates and $21.3 \%$ graduated in education, with an average of 17 years professional experience, although only $25 \%$ have academic training in the field of environmental education versus $75 \%$ who don't have this type of training.

Table 2. \% Provinces teachers.

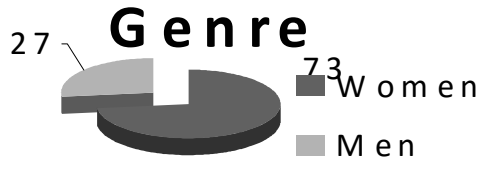

Fig. 2. Genre teachers.

\begin{tabular}{cc}
\hline \multicolumn{3}{c}{$\%$ PROVINCES } \\
\hline Córdoba & $13.5 \%$ \\
Granada & $16.3 \%$ \\
Huelva & $20.2 \%$ \\
Jaén & $26.9 \%$ \\
Málaga & $17.3 \%$ \\
Sevilla & $5.8 \%$ \\
\hline
\end{tabular}

Teacher ages range from 28 to 60 years old, with the average age being 44 years old. With regards to the position they hold at the educational centres, teachers are distributed as follows:

Table 3. Positions held by teachers.

\begin{tabular}{cc}
\hline Positions Held by Teachers & Percentage \\
\hline Tutor & $70.1 \%$ \\
Cycle coordinator & $7.8 \%$ \\
Director & $6.5 \%$ \\
Integration support teacher & $5.2 \%$ \\
Director of studies & $2.6 \%$ \\
Secretary & $2.6 \%$ \\
Administrative & $1.3 \%$ \\
Support to compensatory education & $1.3 \%$ \\
Hearing and speech teacher & $1.3 \%$ \\
Special needs teacher & $1.3 \%$
\end{tabular}

Finally it should be noted that from among the teachers who have participated in the survey, only $17.3 \%$ belong to environmental associations, versus $82.7 \%$ who don't belong to any association.

\section{Analysis of information}

The information that has been taken thanks to the scales have been statistically analysed by basic descriptive analysis (averages, percentages and frequencies), to get to know the relation between some variables we have carried out statistical inferential analysis (statistical contrast). We have carried out this analysis using the statistic programme SPSS v.22.

Regarding the reliability of scales, on the scale corresponding to students, the value of Cronbach's Alpha is 0.771 and the scale aimed at teachers had a Cronbach's Alpha of 0.680, which indicates that these scales are quite reliable. On the scale of teachers' attitudes, items $2,6,7,8,22,30$ and 33 have been worded as negative statements, and this has been taken into account for the analysis, reversing the scale and the values given to those statements. 
For the questionnaire on teaching competences, both the questionnaire addressed to students (with a Cronbach's Alpha value of 0.794) and the questionnaire addressed to teachers (with a Cronbach's Alpha value of 0.903) have quite high reliability indexes, which lends a consistency to the responses obtained.

\section{Analysis of information}

After the analysis of the diverse tools to record information, the following results are obtained:

a) Pro-environmental attitudes

Regarding student attitudes, on a scale from 1 to 3 (where 1 is no and 3 is yes), it is noted that all items have ratings higher than 2 ; which together with the scores of standard deviation, indicate that said ratings are homogeneous, although the lower the averages are, the higher the dispersion is.

Table 4. Attitudes pro-environmental of students.

\begin{tabular}{lcc}
\hline \multicolumn{1}{c}{ Average Ranking: Attitudes pro-environmental of students } & Average & Dev. \\
\hline I like going to the park to play with my friends & 2.92 & .31 \\
Respecting nature is important to me & 2.87 & .38 \\
I try not to throw rubbish on the ground at the playground in my school & 2.83 & .47 \\
I take care of the school's facilities & 2.82 & .45 \\
I comply with my classroom's behavioural rules & 2.81 & .46 \\
I learn how to take care of nature with my family & 2.80 & .49 \\
I take care of the parks in my town or city & 2.80 & .50 \\
\hline I don't usually leave lights on at home & 2.41 & .78 \\
I like watching nature documentaries on TV & 2.41 & .76 \\
At home we use energy efficient light bulbs & 2.38 & .76 \\
I take part in the activities related to nature organised by the Council of my town or city & 2.32 & .77 \\
Public transport stops (tube or bus) are close to my home & 2.20 & .91 \\
\hline
\end{tabular}

The highest rated item, with an average value of 2.92, is related to going to the park to play. These are ages where being with friends is fundamental for child development and social integration. Next, there is a series of items that also rated very well with regards to attitudes of environmental awareness and of caring for their environment, both in their immediate environments (family or school), as well as at a citywide and global environmental level.

The lowest rated items are those related to socio-environmental training and participation. At a local level this population group is not generally taken into account for the participation processes that take place within the municipality, or in the management model that is in place - which is reflected by the two items with the lowest ratings on the survey.

Regarding the teachers, the group's highest rating pro-environmental attitudes (where 1 is totally disagree and 4 strongly agree), are those related to individual behaviours and actions that show commitment to the environment at a local level, that show a degree of conformity with attitudes that relate to favouring sustainable development in their immediate environments (family environment and local context) as is identified by the highest-rated items and the low scores in the standard deviation, which denotes homogeneity in the data. 
Table 5. Attitudes pro-environmental of teachers.

\begin{tabular}{lcc}
\multicolumn{1}{c}{ Average Ranking: Attitudes pro-environmental of teachers } & Average & Dev. \\
\hline I shower instead of bath & 3.96 & .31 \\
I throw rubbish on the ground when nobody is looking & 3.95 & .36 \\
I know what I have to do to save water & 3.88 & .43 \\
We have an obligation to preserve our current natural resources for future & 3.87 & .52 \\
generations & 3.86 & .47 \\
I feel good when I recycle & 3.83 & .43 \\
Local councils should give more importance to the reduction and limitation \\
of noise
\end{tabular}

On the contrary, as can be seen in the table above, those attitudes that relate to a more global sustainable development, that go beyond local contexts and are sustainable attitudes linked to citizen participation in a broad context, are rated lower by teachers, and therefore, are attitudes that are present in this group to a lower extent.

In general, both scales mark the commitments, both individual and socio-environmental, that students and teachers manifest. Whilst pro-environmental awareness and the development of sustainable attitudes at a local level, are assumed and firmly entrenched by both groups, the outstanding subject in educational processes is still a need to work on global environmental awareness, [18, 8].

b) Pro-environmental teacher competences

With regards to the highest rated items, both students and teachers agree on two key competences that teachers develop in the classroom, given the high average ratings as well as the low standard deviations they have, which denote a consensus in the responses. Said competences are related to:

Development of rules around pro-social and healthy behaviours: Both students and teachers point out that the pro-environmental teaching competences that are evolving at their educational centres, with an average rating of 2.86 (out of a possible 3 ) for students and an average teacher rating of 3.83 (out of 4), are those related to pro-social and healthy behaviours, as well as those related to establishing behavioural norms and the development of healthy habits in the classroom.

Work on green awareness: from actions on the environment where the students are taught how to take care of nature (average of 2.79 out of 3), to recycling paper in the classroom itself (average of 3.72 out of 4 ) as indicated by the teachers.

Table 6. Pro-environmental teaching skills.

\begin{tabular}{lcclcc}
\hline \multicolumn{1}{c}{ Students } & Average & Dev. & Average & Dev. \\
\hline $\begin{array}{l}\text { Our classroom has behavioural rules in } \\
\text { relation to our classmates and to taking } \\
\text { care of the school }\end{array}$ & 2.86 & .43 & $\begin{array}{l}\text { You think that working on healthy } \\
\text { habits in the classroom is important }\end{array}$ & 3.83 & .55 \\
$\begin{array}{l}\text { We are taught how to take care of nature } \\
\text { by our teachers }\end{array}$ & 2.79 & .51 & You recycle paper at the centre & 3.72 & .56 \\
$\begin{array}{l}\text { I like working on activities related to } \\
\text { nature with my classmates }\end{array}$ & 2.76 & .53 & $\begin{array}{l}\text { You work on green awareness in the } \\
\text { classroom }\end{array}$ & 3.53 & .67 \\
$\begin{array}{l}\text { We have plants in the classroom } \\
\text { There is a vegetable garden in the }\end{array}$ & 1.73 & .92 & $\begin{array}{l}\text { The school has launched a 21 School } \\
\text { Agenda } \\
\text { You know and take part in the } \\
\text { school's playground }\end{array}$ \\
$\begin{array}{l}\text { processes of 21 Local Agenda of your } \\
\text { town-city }\end{array}$ & 1.32 & .70 \\
\hline
\end{tabular}


On the contrary, with regards to the sustainable management of the centre, both teachers and students are aware of shortcomings of the pro-environmental programs and actions that are developed at their centre in relation to resource management, renewing teacher training and the greening of the centre.

\section{Conclusions}

It has been confirmed that there is a need to redefine the strategies for environmental management, intervention and participation of the entire educational community, approaching this from the design of educationally innovative actions focused on the socioenvironmental problems of the local area (in-service training for teachers, promotion of processes for environmental awareness and communication across the entire educational community, adaptation of the educational centre to the principles of educational sustainability and work on student awareness of greening...).

The undertaking of environmental improvement actions agreed between teachers and students to be performed within educational centres appears as an opportunity for the continuous and effective training on greening the curriculum.

\section{References}

1. Álvarez, P. \& Vega, P., Actitudes ambientales y conductas sostenibles. Implicaciones para la educación ambiental. Revista de Psicodidáctica, 14 (2), 245-260, (2009).

2. Amérigo, M.; Aragonés, J.I.; Sevillano, V.; Cortés, B., La estructura de las creencias sobre la problemática medioambiental. Psicothema, 17 (2), 257-262, (2005).

3. Conde Núñez, M.C., Integración de la educación ambiental en los centros educativos. Ecocentros de Extremadura: análisis de una experiencia de investigación-acción. Tesis doctoral, (2004).

4. Consejería De Medio Ambiente, Estrategia Andaluza de desarrollo sostenible. Sevilla: Consejería de Medio Ambiente. Junta de Andalucía, (2003).

5. Edel, R.; Del Socorro, M.; Ramírez, J., Construyendo el significado del cuidado ambiental: un estudio de caso en educación secundaria. REICE, 4 (1), 52-70, (2006).

6. García, J., Evaluación de la educación para el desarrollo sostenible en universidad en Costa Rica. Tesis doctoral, (2010).

7. Giordan, A., Educación ambiental: principios de enseñanza y aprendizaje. Madrid: Libros de la catarata, (1993).

8. Gutiérrez, J., Latin American narratives of sustainability: opportunities for engagement through films. International Journal of Sustainable Development, 17 (2), 160-175, (2014).

9. Gutiérrez, J. \& Galván, L., Educational Guidance on water under the paradigm of complexity as a result of a comparative study between Spain and Mexico. Manuscript submitted for publication, (2015).

10. López-Alcarria, A., Gutiérrez-Pérez, J. \& Poza-Vilches, M.F., Preschool Education Professionals as Mediators of Environmental Health Education. Procedia - Social and Behavioral Sciences, 132, 639-646, (2014).

11. López-Alcarria, A., Gutiérrez-Pérez, J., Rodríguez-Sabiote, C. \& Poza-Vilches, M.F. The future is in childhood: evaluation of the quality of sustainability programmes in the early years. Manuscript submitted for publication, (2015).

12. Matas, M., Tójar, J.C., Jaime, J.J., Benítez, F.M., Almeda, L., Diagnóstico de las actitudes hacia el medio ambiente en alumnos de secundaria: una aplicación de la TRI. Revista de Investigación Educativa, 22 (1), 233-244, (2004). 
13. Ministerio de Educación, Ley orgánica 1/1990, ordenación general del sistema educativo. Boletín Oficial Del Estado, 238, 28927. http://www.boe.es/boe/dias/1990/10/04/pdfs/A28927-28942.pdf, (1990).

14. Ministerio de Educación, Ley orgánica 2/2006. Boletín Oficial Del Estado, 106, 17158. http://www.boe.es/boe/dias/2006/05/04/pdfs/A17158-17207.pdf, (2006).

15. Ministerio de Medio Ambiente, Libro Blanco de Educación Ambiental en España. Madrid: Secretaría General de Medio Ambiente. Dirección General de Calidad y Evaluación Ambiental, (1999).

16. Ministerio de Medio Ambiente, Educación Ambiental para el desarrollo sostenible. Madrid: Secretaría General de Medio Ambiente. Dirección General de Calidad y Evaluación Ambiental, (1997).

17. Moreno, M., Corraliza, J.A., Ruíz, J.P., Escala de actitudes ambientales hacia problemas específicos. Psicothema, 17 (3), 502-508, (2005).

18. Mizanur, M., Water wars in 21 st century: speculation or reality? International Journal of Sustainable Society, 4(1-2), 3-10, (2012).

19. Poza-Vilches, M.F., Gutiérrez-Pérez, J. \& López-Alcarria, A., The Sustainable View of Childhood: A Case Study in a Metropolitan Municipality. Procedia - Social and Behavioral Sciences, 132, 570-576, (2014).

20. Poza, M.F., Validación empírica de un Modelo de Investigación-Acción Participativa para la implantación de Agendas 21 Locales en la gestión ambiental municipal. Copicentro: Granada, (2009).

21. Quiva, D. \& Vera, L., La educación ambiental como herramienta para promover el desarrollo sostenible. Revista de Estudios Interdisciplinarios en Ciencias Sociales, 12 (3), 378-394, (2010).

22. Vega, P., Freitas, M., Álvarez, P. \& Fleuri, R., Marco teórico y metodológico de educación ambiental e intercultural para un desarrollo sostenible. Revista Eureka sobre Enseñanza y Divulgación de las Ciencias, 4 (3), 539-554, (2007). 